\title{
Interview with Nelly Kornienko
}

\author{
Svitlana Shurma
}

Professor Nelly Kornienko is a Ukrainian art critic, art sociologist, philosopher, scholar of culture, and 'synergist'. She is an academician of the National Academy of Arts in Ukraine as well as a founder, author and director general of the Les Kurbas State Centre for Theatre Arts. ${ }^{1}$ As the author of over 300 scientific publications, she initiated a new approach in the Humanities, and Arts, termed the synergy of art. Her selected works have been translated into 33 languages, with her most recent publications including An Invitation to Chaos. Theatre (Art) and Synergy: A Non-linear Approach (Kyiv, 2010), Non-linear Theatre (Art) Studies: A Post-non-classical View. From Faustus to Proteus (Kyiv, 2013), 'Expansions of the theatre in the time of the quantum. The temptation of radicalism' (in Anais da Academia Brasileira de Ciências, 2018), Theatre and Quantum World: Temptations of Freethinking (Kyiv, 2019). The scholar was nominated for the Kyoto Prize in 2007.

Svitlana Shurma, a co-editor of the current issue, asked Professor Kornienko to respond to several questions regarding Les Kurbas ${ }^{2}$ and Ukrainian theatre. The Professor responded in writing to questions prepared and sent by the interviewer. The answers in Ukrainian were received on 14 September 2019. The following translation into English was done by Svitlana Shurma.

[SSh] Why, in your opinion, should Kurbas' name be mentioned along with such renowned theatre practitioners as Craig, Meyerhold, Stanislavski, Brecht, and others?

[NK] Your question is not really well-phrased ... it would be correct to also mention Artaud, for example ...

Yet, that is not what is important. What is important, though, is that a genius (and here we are talking about a historic role) 'discovers' LAWS. Yes, that's right: these are the laws and they are discovered! And I don't mean elements of aesthetic, ethical, emotional or psychological forms, which may vary almost infinitely.

The foundation of life are the laws and patterns. These also guide the theatre from within its core, and provide it with its welcoming character, energy, and, naturally,

1 See www.kurbas.org.ua for more information.

2 Les Kurbas (1887-1937) was a theatrical reformer, avant-garde theater and film director, playwright, theorist and translator. Kurbas established the modern Ukrainian theatre and greatly influenced it as it progressed to a world-class level during the 1920s and early 1930s. 
philosophy. They also provide the theatre with a sense of itself. They are its peculiar cultural DNA ... The author of such a law - and all the names you have mentioned are those kinds of authors - always offers, for those reasons mentioned, creatively pro-active, advanced strategies, since the law makes the trajectory of the author's perspective tangible. That is why Meyerhold, Artaud, or Kurbas belong not only to the $20^{\text {th }}$ century, but their ideas and laws have the ability to freely circulate in the $21^{\text {st }}$ or $22^{\text {nd }}$ centuries, right along the trajectory...

Quite often critics speak about the influence of one director upon the other, or about one's appropriation of another's aesthetic innovation, without understanding how those laws - which are in fact universal - function. The laws bring forward the logic of aesthetics, forms and scenography. That is why we can trace the 'similar' and 'common' aesthetic forms different directors apply.

For example, it is a well-known historical fact that regarding one of Kurbas' productions critics accused him of appropriation of the innovations Meyerhold had made; yet, Kurbas' premiere had happened much earlier than Meyerhold's ... an immature critique. In fact, Meyerhold's appropriation of Kurbas' aesthetic innovation should have been called out ... However, not recognizing these deeper laws leads to shallow assessments. Unfortunately, those sorts of 'aberrations' were common in the $20^{\text {th }}$ century.

Contemporary theatre studies, in the majority, continue to exploit liberal and ethical replication, clinging to this aberration of vision: descriptiveness and narrativity. And more importantly, some critics do not quite understand how theatre functions, especially when they see the main mission of theatre as re-presentation of society or of some other environment. Do you remember some of the formulas, such as 'theatre is a mirror' or similar outdated statements, that even some of the classic authors held to? We, the new generation of scholars, profess a markedly different opinion regarding the theatre. From our point of view, theatre is a self-organized, open system with high level of freedom and independence, and thus with its own scenarios of development. The most important of these is the understanding of the theatre as a strong Subject with the functions of diagnosing, prognosticating, and insuring its society.

Yet, this is a discussion open for debate, a topic of the alternative theatre studies initiated and developed by the Les Kurbas Centre...

I hope this answers your question.

[SSh] Why is Les Kurbas' name less known around the world compared to the names of Meyerhold and Tairov, for example?

[NK] Kurbas' name was forgotten during the past two decades in the Western world, although in 1930s Kurbas' students and admirers had to a degree promoted interest in his name in the USA... For instance, La MaMa E.T.C. ${ }^{3}$ as well as Yara Arts Group

3 La MaMa Experimental Theater Club was founded in 1960s by Ellen Steward as an Off-Off-Broadway theater in the East Village. Today La MaMa is seen as a cultural ambassador for Off-Off-Broadway theater that has staged works by various artists from over seventy countries, including Ukraine. See http://lamama.org for more information. 
directed by Virlana Tkacz ${ }^{4}$ continue to popularize and experiment with Kurbas' legacy as part of the Off-Off-Broadway tradition.

Principally, this lack of knowledge is explained by purely historical events that interfered with the dissemination of tradition: the Executed Renaissance ${ }^{5}$ and totalitarianism that even after Kurbas' exculpation continued to 'erase' the memory of the director by state bans, and of course the lives of those who wanted to discover or popularize Kurbas were conditioned by these bans...

Psychological fascism distorted human values, which had an adverse effect on the Ukrainian theatre: 'erasing' Kurbas' name from history was damaging, since at some point the Ukrainian theatre was not even aware of philosophical and intellectual theatre and humanistic ethics, in which the protection of any individual was the inherent and dominating value. For a number of generations, this thin thread of Gogol's ethics and aesthetics had remained torn...

Luckily, a few things have changed since Ukraine became independent. The Les Kurbas Centre has devoted its energies to returning the name of the renowned modernistinnovator and creator of the Ukrainian national theatre at European art standards to world prominence in culture and science. Les Tanyuk, a director, script writer, translator, Ukrainian political activist, was the first who insisted on this ... The Les Kurbas Centre, initiated by Tanyuk, undertook this mission.

Moreover, contemporary research has led to a number of dissertations and monographs, presentations in Europe, articles, international conferences (in Poland, France, Russia, Latvia, Germany, Canada as well as other countries), all dedicated to Kurbas, including a conference in Kurbas studies in which European scholars also participated, multi-author monographs, and joint projects with scholars from Poland, the USA, France and elsewhere. Presentations on Kurbas' innovations given in France and Austria are also worth mentioning.

The Les Kurbas Centre not only supports research connected with the director's practices and beliefs but is also interested in other theatrical innovations as well as state-ofthe-art research into theatrical processes, including Kurbas' ethics. As I have mentioned, we have initiated a new approach in the humanities and theatre studies in particular ...

[SSh] How is Les Kurbas theatre connected to European theatre (possibly to the aesthetics of Otakar Zich)?

[NK] Talking about the connection as such, we see it in the poetics of Philippe Genty, Christoph Marthaler, Romeo Castellucci, Robert Wilson and in that of other European

4 Virlana Tkacz is the founder of Yara Arts Group, a resident company at La MaMa E.T.C. She is known for her experimentation and collaboration with experimental theater companies from Eastern Europe.

5 The term Executed Renaissance refers to a 1920 - early 1930s generation of Ukrainian artists, writers, philosophers and clerics who were executed or repressed during the Stalinist period. Three hundred Ukrainian writers and other artists were shot dead at Sandarmokh in Karelia, Russia during 1937-1938. Les Kurbas was executed along with other Ukrainian writers and artists on 3 November 1937. His widow was informed that he had died of blood-stroke on 15 November 1942. The order of his exculpation was issued only in 1957. 
and world-renowned directors' poetics. This is especially true about those who take the hardest path - the path of finding deeper energies, experimenting with the subconscious, engaging with the formulas of Kurbas' 'imaginative transformation' ${ }^{\prime} \ldots$ I do not wish, however, to make this complicated idea sound simple ...

Speaking of Otakar Zich, I can only say that the Prague School occupies a prominent place in structuralist breakthroughs in linguistics, literary and theatre studies, superior even to that of French structuralism. I read mainly Mukařovský, to whom the Prague School owes its most important discoveries; nevertheless, Otakar Zich's contribution and influence was no less important. Zich's functional approach to text as an inner 'identity', to the inherent value of its inner qualities, possibility of influences inside the text and at the same time the importance of recipients' reflections and emotions, and inclusion of their potential interpretations is what, in my opinion, makes him so significant in the modern European theatre research. His ideas are yet to be re-evaluated...

[SSh] What is the Les Kurbas State Centre for Theatre Arts working on now, and how does it promote Ukrainian theatre around the world?

[NK] The Les Kurbas Centre does not promote Ukrainian theatre around the world. Yet, among its many activities the centre has undertaken an ambitious mission to help Ukraine re-integrate into Europe through innovations in theatre research and in the humanities. Moreover, we advocate the model of the future society for Europe: a society founded on Culture. It is culture that can lift up economies, an experience that several European states have already been through.

For the reasons above, our sphere of activity is multi-faceted: theatre and performance experimentation, fundamental theory, culturology, cinema studies, educational, drama and choreographic projects, workshops, summer schools and residences. The Centre lives by its senses and values. Especially these days, as war has come to Ukraine, we see the value of national identification and solidarity, and the stimulation of heart-felt energy as our priorities. A part of our aesthetic code is provoking critical thinking and Freedom in the society. There was definitely a reason for standing there along with others at the Maidan of Dignity ${ }^{7}$ for 90 days...

Would you like to know our motto?

'Come to us with your craziest ideas - only these will find their way!'

Translated from Ukrainian by Svitlana Shurma

6 'Kurbas' idea of a new, philosophical theater (whose ultimate aim was to return to theater's ritualistic roots and once again become a religious act) demanded a new type of actor. Rather than reliving the character's emotions or identifying with him or her, Kurbas' actor was supposed to objectify the character through the complete control of his or her body and voice and by means of several key techniques. The most important technique, transformation (peretvorennia), represented a theatrical symbol designed to reveal the spiritual and hidden elements by way of concrete images.' (HAIEVSKY and STECH 2006)

7 The Revolution of Dignity or the Ukrainian revolution of 2014 took place mainly at Maidan Nezalezhnosti (Independence Square), a central square in Kyiv. The violent protest led to the ousting of President Viktor Yanukovych and the overthrow of the elected government. 


\section{Bibliography}

HAIEVSKY, Valentyn and Marko Robert STECH. 2006. Kurbas, Les [online]. In Internet Encyclopedia of Ukraine. 2006. [accessed 4. 12. 2019]. Available online at: http://www.encyclopediaofukraine.com/display.asp?linkpath=pages\%5CK\%5CU\%5CKurbasLes.htm 
